研究論文

\title{
小型コンプレッサを用いた空気圧アクティブサスペンションの制御*
}

\author{
カハル・サムサク**，則 次 俊 郎**
}

\section{Control of a Pneumatic Active Suspension with a Small Compressor}

Kahar SAMSAK and Toshiro NORITSUGU

In order to improve the vibration isolation performance and to decrease the energy consumption of an active suspension with a pneumatic cylinder, a frequency dependent control, an energy regenerating control and so on have already been developed. In this study, to build up a stand-alone type active suspension which reconciles vibration isolation performance and energy savings, a driving system comprising a small sized compressor and an energy regeneration circuit is proposed. From some experiments, the control performance of the proposed system is investigated. The results show the feasibility of the proposed system.

Key Words: Pneumatic active suspension, Compressor control, Energy saving, Vibration control, Skyhook control

\section{1.はじめに}

自動車のサスペンションの役割として，路面からの振動 の絶縁や操縦安定性の確保がある。近年，快適性を損なう ことなくより一層の操縦安定性の確保が要求されており, サスペンションの高性能化が必要不可欠なものとなってい る.

空気圧シリンダをアクチュエータとして用いた車両用ア クティブサスペンション ${ }^{1,2}$ を対象とし，これまでに制振 性能の向上とエネルギー消費の低減を目的として，周波数 依存型制御法 ${ }^{3 /, 4)}$ やエネルギー回生制御法 ${ }^{5}$ などを提案して いる. 今後，これらの実用化を進めるためにはアクチュ エータ（空気圧シリンダ）の駆動エネルギーを供給するコ ンプレッサの選定が重要な課題となる.コンプレッサの選 定は省エネルギーの立場から避けて通れない問題である. また，車両への搭載を考えた場合，コンプレッサを内蔵し た空気圧駆動システムの構築が必要である. 本研究では, このようなシステムの開発を目的として, 市販の小型コン プレッサを用いてアクティブサスペンションおよびエネル ギー回生制御手法を取り入れたエネルギー回生サスペン ションを構成し, 制振性能と省エネルギーを雨立させるた めのコンプレッサおよびサスペンションの制御手法を提案 する．まず，駆動システムの構成について記述した後，実 験結果に基づいて, 構成した駆動システムの有効性を示す.

\footnotetext{
*平成 13 年 9 月 25 日 原稿受付

**周山大学工学部

(所在地 $\bar{\top} 700-8530$ 岡山市津島中 3-1-1)

E-mail : toshiro@sys.okayama-u.ac.jp
}

\section{2. 駆動システムの構成}

\section{1 コンプレッサ制御システム}

Fig. 1にコンプレッサ制御システムの構成を示す. 図中 のコンプレッサ部分には, Table 1に示す仕様を有する日 東工器侏製の 2 台の小型コンプレッサが並列に接続され ている.

圧力タンクの容積は $10 l$ であり，圧力センサを取付けて タンク内の圧力 $P_{t 1}$ を検出する.

コンプレッサはSSR（Solid State Relay）交流用スイッ チによりオンオフ（駆動あるいは停止）制御する. SSRス イッチング回路のオンオフ条件は次式で与えられる.

$$
\begin{aligned}
& P_{t 1}<P_{d} \\
& P_{t 1} \geq P_{d}
\end{aligned}
$$

$P_{d}$ はコンプレッサに要求されるタンク内目標圧力である.

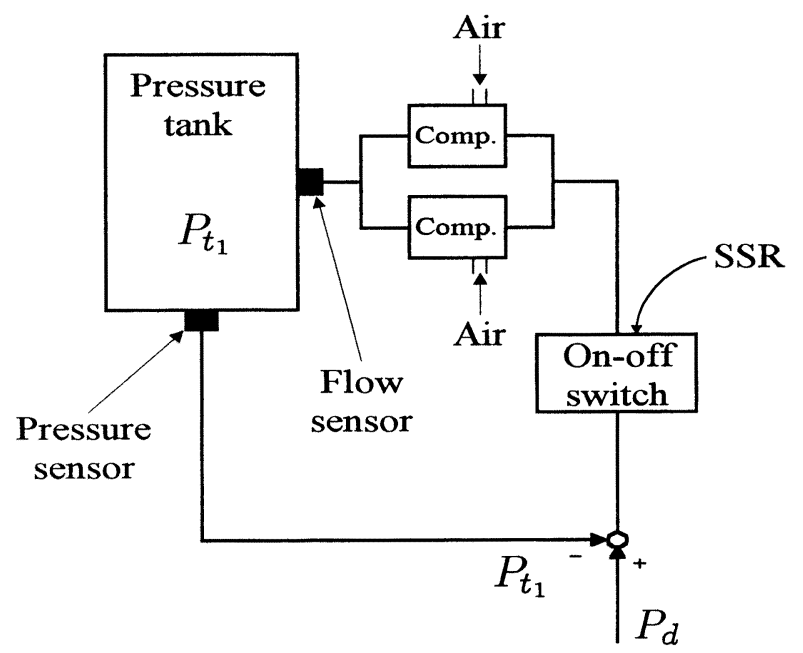

Fig. 1 Compressor control system

$$
\text { - } 7 \text { - 2002年 } 5 \text { 月（平成14年） }
$$


Table 1 Specification of small sized compressor

\begin{tabular}{|c|c|c|}
\hline Rated pressure & 100 & {$[\mathrm{kPa}]$} \\
\hline Outlet flow & 16 & {$[\mathrm{l} / \mathrm{min}]$} \\
\hline Rated voltage & $\mathrm{AC} 100$ & {$[\mathrm{~V}]$} \\
\hline Rated frequency & $50 / 60$ & {$[\mathrm{~Hz}]$} \\
\hline Electric power & $90 / 85$ & {$[\mathrm{~W}]$} \\
\hline Ampere & 2.2 & {$[\mathrm{~A}]$} \\
\hline Mass & 4.9 & {$[\mathrm{~kg}]$} \\
\hline
\end{tabular}

式(1)の状態ではコンプレッサを駆動し，式(2)の状態ではコ ンプレッサを停止させる.ここでは, 最も単純なオンオフ 制御を用いる.

上述の制御方式を用いて，コンプレッサの目標圧力 $P_{d}$ を 100 秒間隔で $P_{d}=100 ， 150,200[\mathrm{kPa}]$ に設定した時の夕 ンク内圧の時間的変化をFig. 2に示す. 目標圧力に達す るまでに10〜15秒程度の時間がかかるが，その後は目標 圧力を維持している.ここではタンクから空気の放出はな い. な扔，目標圧力に達するまでの時間はタンクの容積に 依存する。

Fig. 1のコンプレッサ制御システムの圧力・流量特性 ( $\mathrm{P}$ -Q図）をFig. 3に示す. 流量が $Q=32 \sim 35[\mathrm{l} / \mathrm{min}]$ 以下

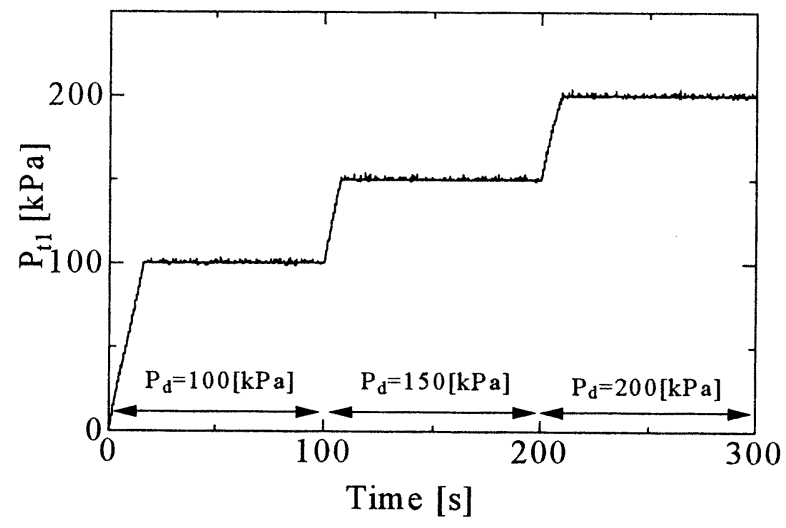

Fig. 2 Pressure response in tank

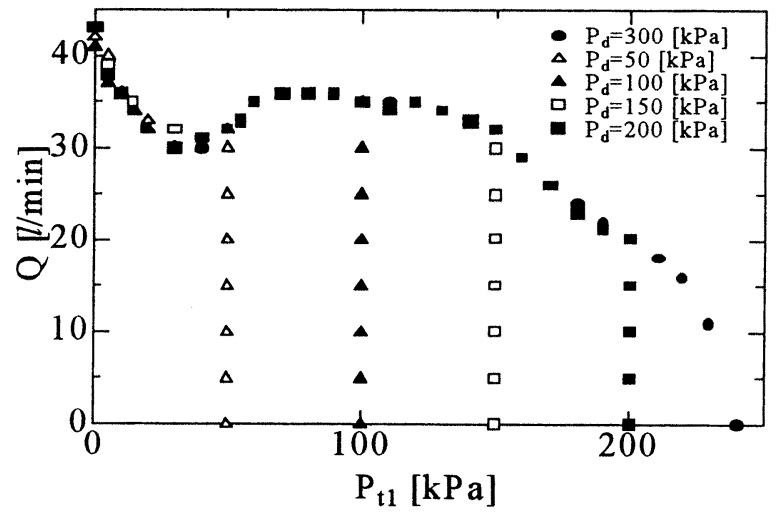

Fig. 3 Characteristics of compressor control system
の範囲内において，タンク内圧力は目標圧力 $P_{d}=50,100$, $150[\mathrm{kPa}]$ の值を保ち, $Q=20[\mathrm{l} / \mathrm{min}]$ 以下では, $P_{d}=$ $200[\mathrm{kPa}]$ 以上の圧力を維持できる.これより, 本研究 で提案する小型コンプレッサシステムは有効であると考え られる。

\section{2 サスペンション制御システム}

実験で用いる 1 軸のサスペンション装置をFig. 4に示す. 車体に相当するばね上質量，車軸に相当するばね下質量， タイヤに相当する空気ばねが設置されており，空気ばねの 下部から油圧加振機により振動を与える.コイルばねと平 行に空気圧シリンダと減衰力可変ダンパが設置されている. 本研究では減衰力可変ダンパは最もソフトの状態に設定さ れている. 空気圧シリンダとダンパによりアクティブサス ペンションが構成され, 油圧加振機により与えられた振動 の車体への伝達を抑制する.

Fig. 5は小型コンプレッサを用いたサスペンション制御 システムの構成を示す. 空気圧シリンダと流量制御弁 （サーボ弁）により空気圧サーボ機構を構成し，目標とす る制振力を発生させる．目標とする制振力を決定するため の制御則としてスカイフック理論を用いる．スカイフック

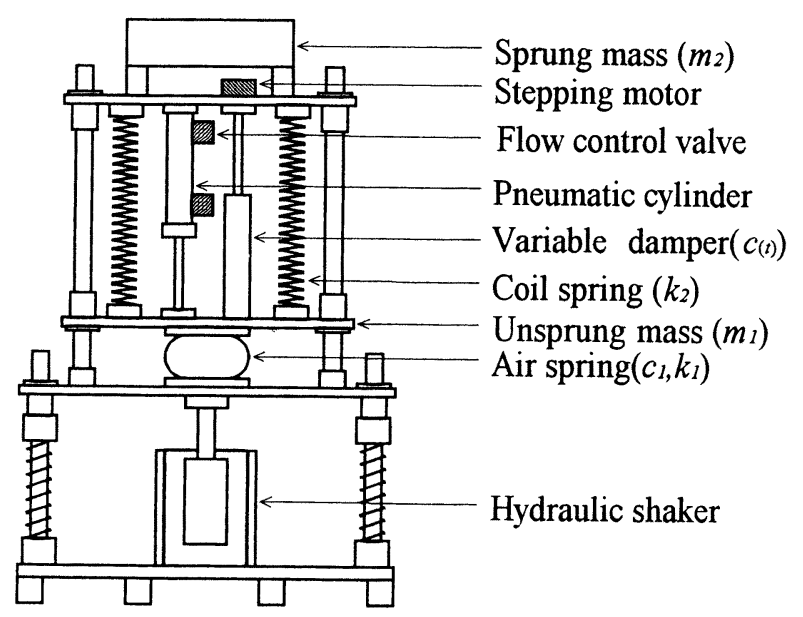

Fig. 4 Structure of exprimental suspension

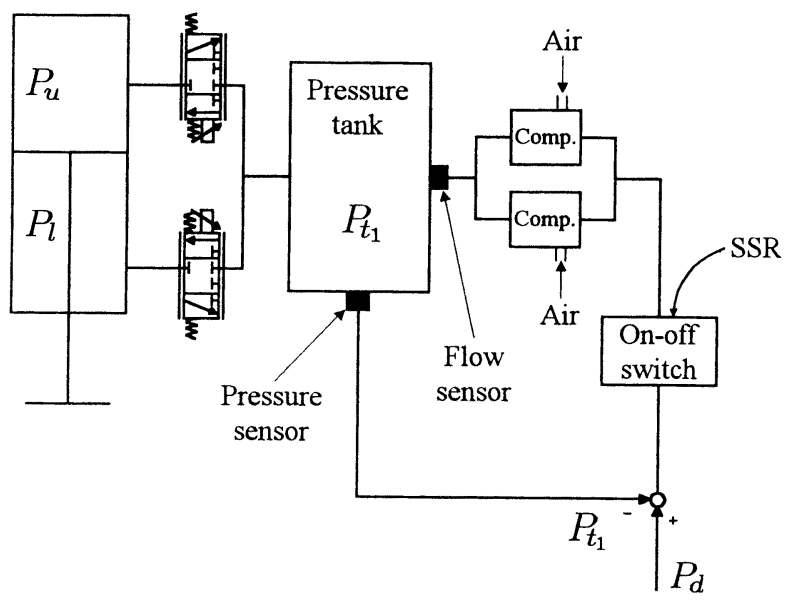

Fig. 5 Suspension control system 
理論では車体の鉛直方向速度に比例する隇衰力を発生させ るため, ばね上質量（車体）の速度をフィードバック信号 として用いる.

目標とする制振力 $f_{r}$ ，これを実現するための上下シリン 名室の目標圧力 $P_{u r}, P_{l r}$ は次式により与えられる

$$
\begin{aligned}
& f_{r}=-c_{s} \dot{x}_{2} \\
& f_{r}=P_{u r} A_{u}-P_{l r} A_{l} \\
& P_{u r}=P_{u 0}+f_{c} / 2 A_{u} \\
& P_{l r}=P_{10}-f_{c} / 2 A_{l}
\end{aligned}
$$

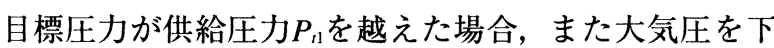
回った場合には以下の式を用いてできるだけスカイフック 理論により要求される目標発生力を確保する.

$$
\begin{aligned}
& \text { if } P_{u r}>P_{t 1} \text { then } P_{u r}=P_{t l}, P_{l r}=\frac{A_{u}}{A_{t}} P_{t 1}-\frac{f_{r}}{A_{l}} \\
& \text { if } P_{u r}<0 \text { then } P_{u r}=0, P_{l r}=-\frac{f_{r}}{A_{l}} \\
& \text { if } P_{l r}>P_{t l} \text { then } P_{t r}=P_{t l}, P_{u r}=\frac{A_{l}}{A_{u}} P_{t 1}+\frac{f_{r}}{A_{u}} \\
& \text { if } P_{l r}<0 \text { then } P_{l r}=0, \quad P_{u r}=\frac{f_{r}}{A_{u}}
\end{aligned}
$$

添字 $u ，$ はそれぞれ上部および下部シリンダ室を示し， $r$ は目標値を示す． $\dot{x}_{2}$ は車体の速度であり， $A_{u} ， A_{l}$ はそれぞ れ上部および下部シリンダ室の断面積である， $P_{u 0}, P_{10}$ は 上部および下部シリンダ室の平衡圧力であり, 次式により 与える。

$$
\begin{aligned}
& P_{\text {แ0 }}=\frac{1}{2} P_{t 1} \\
& P_{10}=\frac{A_{u}}{A_{1}} P_{40}
\end{aligned}
$$

\section{3 エネルギー回生制御システム}

エネルギーの有効利用を図るために，エネルギー回生制 御を行う。これは，従来大気中に排気していた空気を回収 し，外部に取り付けたセービングタンクを通して再利用す るもので，これにより供給源（コンプレッサ）からの供給 流量を低減することができる．本研究で用いるエネルギー 回生制御システムをFig. 6に示す.

オンオフ弁 1 を通して下部シリンダ室からの排出空気 をセービングタンクに回収し，オンオフ弁 2 を通して回 収した空気を再び下部シリンダ室に供給する，上部シリン ダ室へはセービングタンクのみから供給する．各オンオフ 弁の切換えは次の条件にしたがって行われる.

$$
\begin{aligned}
& P_{l}>P_{12} \\
& P_{12}>P_{l}+\delta P_{1}
\end{aligned}
$$

式(13)において，下部シリンダ室の圧力 $P_{l}$ がセービングタ ンクの圧力 $P_{22}$ より高い場合には, 弁 1 をオンにしセービ ングタンクへ排出空気を回収する．そうでない場合には, 大気へ排出する. 式(14)に扔いて，セービングタンクの圧力 が下部シリンダ室圧力よりある一定值 $\delta P_{1}$ だけ高くなると,

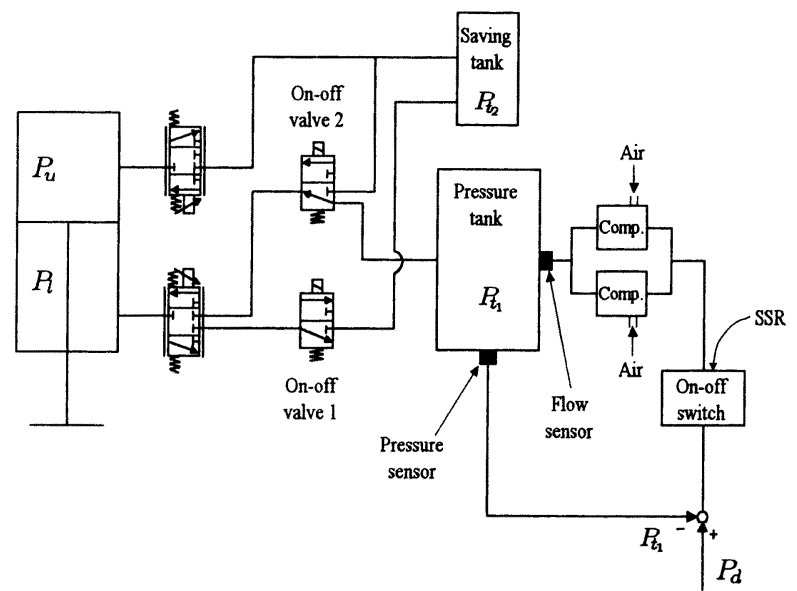

Fig. 6 Suspension control system and regeneration

弁 2 をオンにし，セービングタンクより下部シリンダ室 へ空気を供給する，そうでない場合には，供給源（pressure tank）より供給する. 式(14)の $\delta P_{1}$ はエネルギー回生 制御が㗢くために必要な閾値である

\section{3．実験装置および方法}

\section{1 実験装置}

Fig. 4の実験装置を用いて，Fig. 5の小型コンプレッサ を用いた場合とFig. 6のエネルギー回生システムを併用し た場合について制振性能とエネルギー消費量を測定する。 実験装置のシステムパラメータをTable 2に示す。

Table 2 System parameters

\begin{tabular}{|l|c|c|c|}
\hline Sprung mass & $m_{2}$ & 136 & {$[\mathrm{~kg}]$} \\
\hline Unsprung mass & $m_{1}$ & 66 & {$[\mathrm{~kg}]$} \\
\hline Damping coeffcient of air spring & $c_{1}$ & 300 & {$[\mathrm{Ns} / \mathrm{m}]$} \\
\hline Stiffiness of coil spring & $k_{2}$ & 41.2 & {$[\mathrm{kN} / \mathrm{m}]$} \\
\hline Stiffiness of air spring & $k_{1}$ & 150 & {$[\mathrm{kN} / \mathrm{m}]$} \\
\hline Upper part of cylinder & $A_{u}$ & 19.63 & {$\left[\mathrm{~cm}^{2}\right]$} \\
\hline Lower part of cylinder & $A_{l}$ & 15.83 & {$\left[\mathrm{cmil}^{2}\right]$} \\
\hline
\end{tabular}

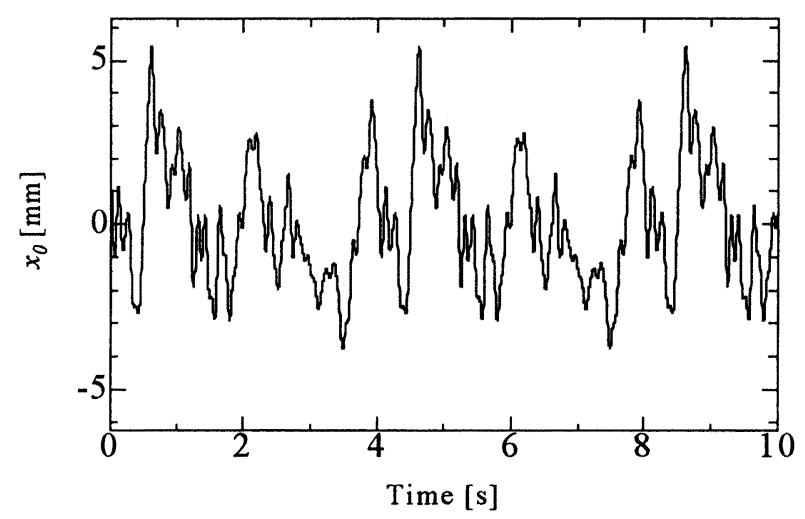

Fig. 7 Disturbance from road Surface 2002年 5 月（平成14年） 
油圧加振機により，Fig.7に示すような，0.1〜11 [Hz] までの複数正弦波を位相をずらせて重ね合わせたランダム 加振入力を与える.

上部および下部シリンダ室において，それぞれ上記の目 標圧力 $P_{u r}$ および $P_{l r}$ に対して比例制御によるフィードバッ ク制御系を構成する.比例制御ゲインを $k_{p}=0.12[\mathrm{~V} /$ $(\mathrm{kPa})]$ ，スカイフックダンパの減衰係数は $c_{s}=2000[\mathrm{Ns} /$ $\mathrm{m}$ ]に設定する.

\section{2 実験方法}

まず，コンプレッサを常時駆動（Full drives，すなわち $P_{d}$ をコンプレッサの最大吐出圧力 $240[\mathrm{kPa}]$ （Fig. 3を参 照）以上の $300[\mathrm{kPa}]$ に設定）し，Fig.5のシステムを用 いた場合の制振性能と消費エネルギー（アクチュエータ駆 動用の消費流量とコンプレッサ駆動用の消費電力量）を測 定し，比較の基準とする.

次に, 目標圧力 $P_{d}$ を空気圧シリンダの上部，下部シリン ダ室の目標圧力に沿わせるように， $P_{u r}$ と $P_{t r}$ の大きい方に 設定し，次式で与える。これにより，Fig. 5およびFig. 6 のシステムに対して実験を行う。

$$
P_{d}=\max \left(P_{u r}, P_{t r}\right)+\delta P_{d}
$$

ここで， $\delta P_{d}$ は供給圧力に余裕を持たせるための補正項で ある.

本研究では制振性能とエネルギー消費について評価を行

う. 制振性能の評価は加振機による加振加速度（路面加速 度）と車体加速度の振幅比により評価する．以下で示す加 速度振幅比 $\left.\ddot{x}_{2} / \ddot{x}_{0}\right)$ はパソコン内に構成したフーリエ変換 により求めたものである.アクチュエー夕駆動用の空気消 費流量とコンプレッサ駆動用の消費電力量を消費エネル ギーとする. 空気圧供給源に取り付けた流量センサ （STEC製，SEF-22A）と電力計（横河製，WT200）に より供給体積流量と電力量を測定する，流量センサは熱線 流速系の原理を応用した熱式質量流量系であり，大気圧換 算の体積流量の瞬時値を表示するものである. 個々の実験 は 5 分間実施する，消費流量は実験全体 (5 分間) での 蓄積流量を 1 分当たりに平均したもので，電力量は 5 分 間の蓄積電力量である．なお，消費エネルギーにはシステ 厶始動から定常状態になるまでのエネルギーも含まれてい る.

\section{4. 実験結果および考察}

\section{1 サスペンション制御システム}

Fig. 8にFull driveのときの制振性能をパッシブサスペ ンション（空気圧シリンダに空気を供給しないサスペン ション) の性能とともに示す. Fig.8より, Full driveは パッシブサスペンションに比べて，ばね上共振点 $2.5[\mathrm{~Hz}]$ 付近を含む $2 \sim 4[\mathrm{~Hz}]$ の低周波領域で大きな改善が見 られる。

次に, 小型コンプレッサの目標圧力 $P_{d}$ を式(15)で定め, 圧

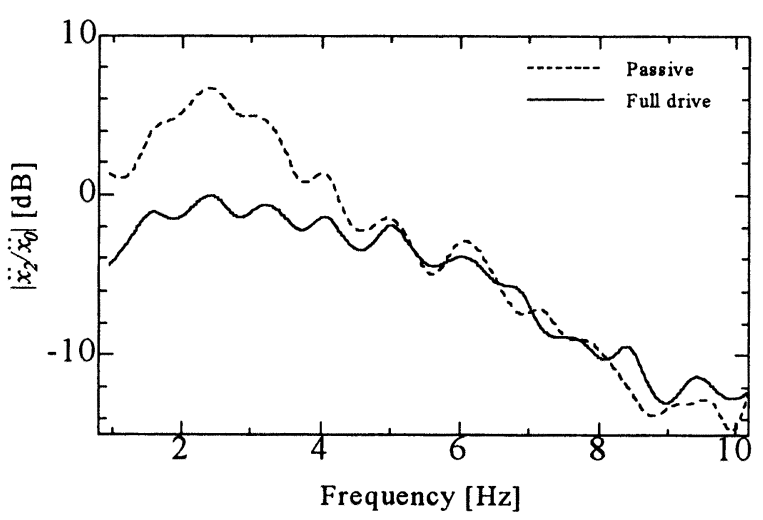

Fig. 8 Frequency response (Full drive, Passive)

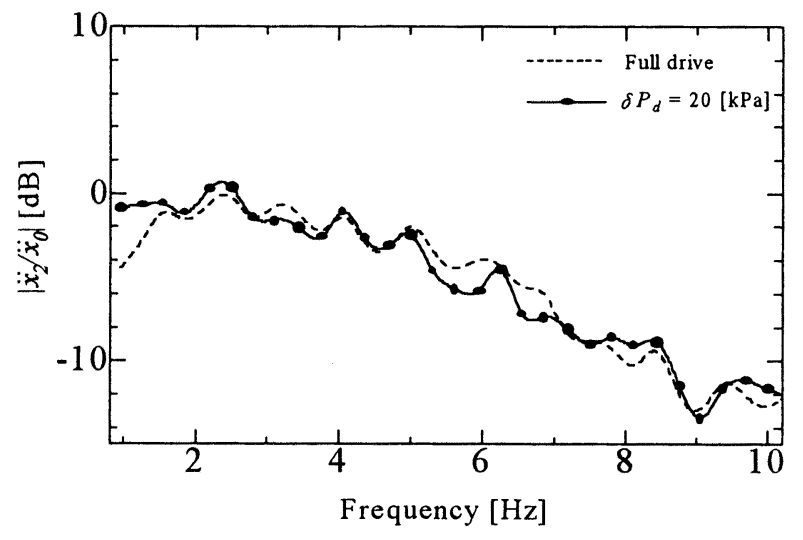

Fig. 9 Frequency response

Table 3 Flow and power consumption

\begin{tabular}{|c|c|c|}
\hline $\begin{array}{c}\text { Pressure } \\
{[\mathrm{kPa}]}\end{array}$ & $\begin{array}{c}\text { Flow rate } \\
{[1 / \mathrm{min}]}\end{array}$ & $\begin{array}{c}\text { Electric power } \\
{[\mathrm{Wh}]}\end{array}$ \\
\hline Full & 60.98 & 12.64 \\
\hline$\delta P_{d}=40$ & 54.05 & 11.43 \\
\hline$\delta P_{d}=30$ & 46.82 & 10.36 \\
\hline$\delta P_{d}=20$ & 39.73 & 9.31 \\
\hline
\end{tabular}

力補正項 $\delta P_{d}=20[\mathrm{kPa}]$ とし, 実験を行った。この場合 の制振性能をFig. 9, エネルギー消費量をTable 3に示す. Fig. 10はこのときの圧力の時間応答で, Fig. 11はスカイ フック理論により計算される目標制振力 $f_{r}($ 式(3)) とシリ ンダが実際に発生している力 $f_{c}\left(f_{c}=P_{u} A_{u}-P_{l} A_{l}\right)$ の時間応答 である. Fig. 9より, Full driveと比較して, ばね上共振 点付近でやや制振性能の悪化が見られたが， $5 \sim 7 \quad[\mathrm{~Hz}]$ では若干向上している.このように, Full driveとほほ同 様な制振性能が得られた原因としては，コンプレッサの目 標圧力を, 式(15)よりシリンダの目標圧力で与えるために, Fig. 10, Fig. 11の圧力および力の時間応答より, 244.5秒, 246.0 秒， 248.5秒付近などで下部シリンダ室の圧力と発 生力の不足が少々生じるものの, 全体としては空気圧シリ ンダの圧力と発生力が目標圧力および目標制振力に追従し ていることによるものと考えられる. 


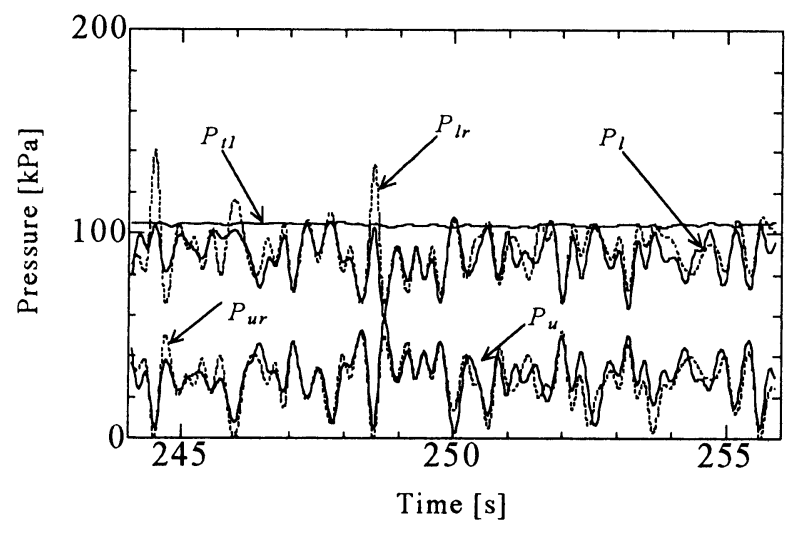

Fig. 10 Time response of pressure

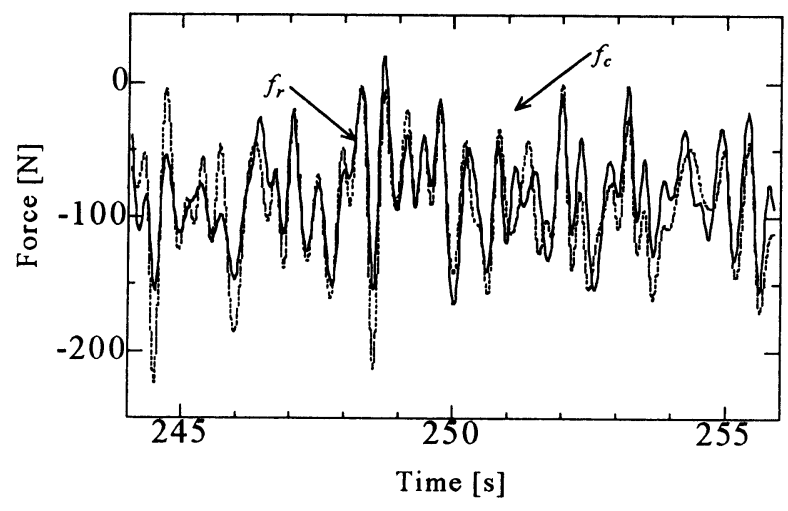

Fig. 11 Time response of force

なお，圧力補正項 $\delta P_{d}$ を大きくすればアクチュエータの 供給圧力が高くなり, 制振性能の向上が期待できるが，消 費エネルギーが増加する，逆に， $\delta P_{d}$ が小さいと消費エネ ルギーは減少するが, 制振性能が悪化する恐れがある. 本 研究では，これらを考慮して $\delta P_{d}=20[\mathrm{kPa}]$ に設定して

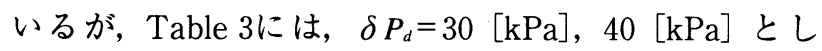
た場合の空気消費流量と消費電力を合わせて示す。これら

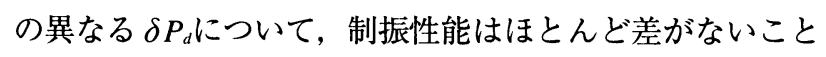
が確認されている．また，当然のことながら $\delta P_{d}$ が小さい ほど消費エネルギーが少なく, $\delta P_{d}=20[\mathrm{kPa}]$ の場合に はFull driveに比べて, 空気消費流量で約 $34.8 \%$, 消費電 力で約 $26.3 \%$ 低減している. なお， $\delta P_{d}$ を $20[\mathrm{kPa}]$ 以下 に設定するとアクチュエータへの供給圧力の不足により制 振性能が低下した.このように，コンプレッサの目標圧力 を上部・下部シリンダ室の目標圧力の高い方を基準に設定 することにより, 制振性能を維持しつつエネルギー消費を 低減させることができる.

\section{2 エネルギー回生制御システム}

次に,さらにエネルギー消費量を低減するために,

Fig. 6のエネルギー回生制御システムを用いる. 圧力補正 項 $\delta P_{d}$ は同様に $\delta P_{d}=20[\mathrm{kPa}]$ とした. 制振性能および エネルギー消費をそれぞれFig. 12, Table 4に示す。また， Fig. 13は圧力の時間応答, Fig. 14は目標制振力 $f_{r}$ とシリン ダが実際に発生している力 $f_{c}$ の時間応答である. $f_{c}$ は上部

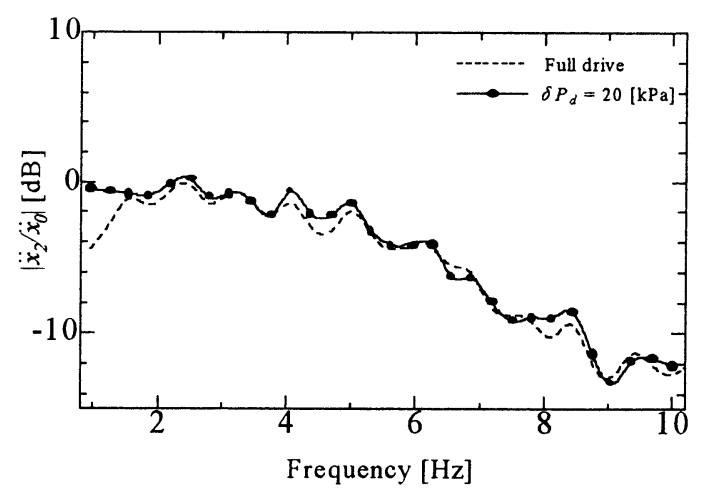

Fig. 12 Frequency response (Regeneration)

Table 4 Flow and power consumption (Regeneration)

\begin{tabular}{|c|c|c|}
\hline $\begin{array}{c}\text { Pressure } \\
{[\mathrm{kPa}]}\end{array}$ & $\begin{array}{c}\text { Flow rate } \\
{[\mathrm{l} / \mathrm{min}]}\end{array}$ & $\begin{array}{c}\text { Electric power } \\
{[\mathrm{Wh}]}\end{array}$ \\
\hline Full & 60.98 & 12.64 \\
\hline$\delta P_{d}=40$ & 34.43 & 8.12 \\
\hline$\delta P_{d}=30$ & 29.64 & 6.74 \\
\hline$\delta P_{d}=20$ & 26.94 & 6.44 \\
\hline
\end{tabular}

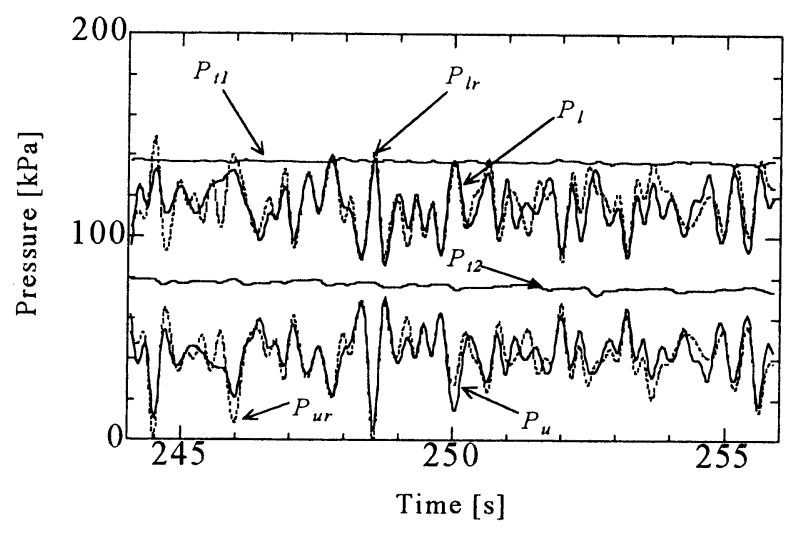

Fig. 13 Time response of pressure which energy regeneration

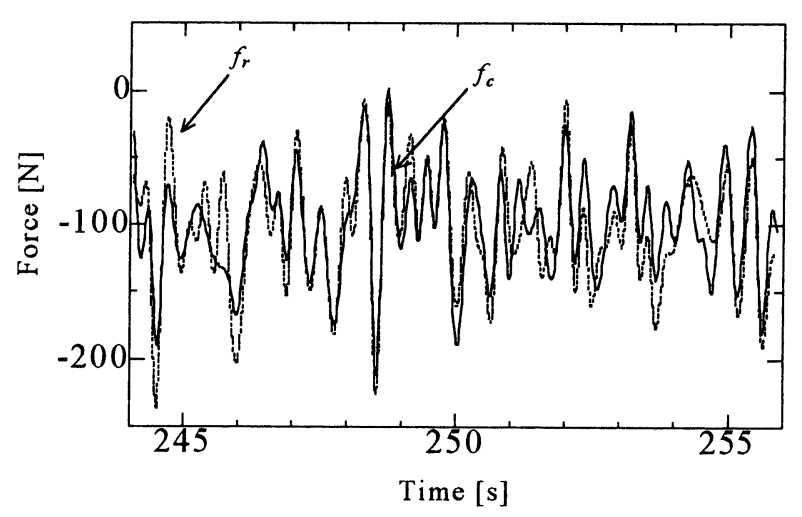

Fig. 14 Time response of force which energy regeneration 
および下部シリンダ室圧力の測定值を用いて, $f_{c}=P_{u} A_{u}-$ $P_{l} A_{l}$ より計算したものである.

Fig. 13に示すようにセービングタンク内の圧力 $P_{t 2}$ は上 部シリンダ室の圧力より高く, セービングタンクに回収し た排気空気だけによって上部シリンダ室への給気が可能で ある.これによりコンプレッサの負担が軽減され，その結 果, 供給源圧力としての $P_{t 1}$ を比較的高圧に維持すること ができる.そのため，Fig.12に示すように，制振性能は Full driveに比べてほとんど悪化が見られない，また，消 費エネルギーは， $\delta P_{d}=20[\mathrm{kPa}]$ の場合に, Full drive に比べて, 空気消費流量で約 $56 \%$, 消費電力で約 $49 \%$ も の低隇が可能である.

\section{5.おわりに}

本研究では，小型コンプレッサを用いたアクティブサス ペンションおよびエネルギー回生制御手法を取り入れたエ ネルギー回生アクティブサスペンションを構成し, 制振性 能と省エネルギーを両立させるためのコンプレッサおよび サスペンションの制御手法を提案した.

構成したアクティブサスペンションシステムは制振性能 の面において，パッシブサスペンションょり性能がよいこ とを確認できた.

コンプレッサの目標圧力をシリンダの目標圧力で与える ことにより，良好な制振性能を保つだけでなく, 高周波に おいては改善もなされた，これにより，エネルギーの有効 利用が図れた。
目標圧力を最適に与えることに加えて，エネルギー回生 制御を行うことによりさらなるエネルギー消費量の低隇が なされた。

以上の結果より, 本研究で構成したアクティブサスペン ションシステムは良好な制振性能を維持しつつ, エネル ギー消費量を大幅に低減させることができ，車両への搭載 が期待できる.

\section{参 考 文 献}

1）カヤバ工業株式会社編，自動車のサスペンション，山 海堂, 1991

2）松下尚史, 則次俊郎, 堂田周治郎：予見フィードフォ ワード制御による空気圧駆動式アクティブサスペン ションの性能向上，日本機械学会論文集（C編） 59 巻563号, pp. 166-172, 1993

3 ) Noritsugu T., Sanada S., Takehara S., Energy Saving Control of Hybrid Type Pneumatic Active Suspension, Proc. of Japan USA Symposium, pp. 167-172, 1996

4 ）則次俊郎，須賀康博，田原吉則：周波数フィルタを応 用したハイブリッドエアサスペンシュンの省エネル ギー制御, 日本機械学会論文集 (C 編) 66巻641号, No. 99-0608, pp. 112-117, 2000

5 ) 則次俊郎, Kahar Samsak, 高取弘之：エネルギー回 生空気式アクティブサスペンションの開発, 日本機械 学会論文集（C編）66巻648号, pp 113-118，2000 